\title{
THE PRIORITY DIRECTIONS OF INTEGRATION OF OBSTETRICAL AND GYNECOLOGICAL CARE TO THE FEMALE POPULATION OF UKRAINE AT THE PRIMARY LEVEL
}

DOI: 10.36740/WLek202103215

\author{
Olena S. Shcherbinska', Hennadiy 0. Slabkiy ${ }^{2}$ \\ 'SHUPYK NATIONAL MEDICAL ACADEMY OF POSTGRADUATE EDUCATION, KYIV, UKRAINE \\ ${ }^{2}$ UZHHOROD NATIONAL UNIVERSITY, UZHHOROD, UKRAINE
}

\begin{abstract}
The aim: To determine the priority directions for the integration of obstetric and gynecological care for the female population of Ukraine to the primary level of its provision. Materials and methods: Sociological, statistical and bibliosemantic methods were used in the research. The systematic approach was the methodological basis of the study. 79 health care providers, 127 family doctors, 92 doctors of obstetrics and gynecology, and 248 women of reproductive age were interviewed as experts using a special questionnaire. Results: Some priority management and organizational measures that need to be carried out for the effective integration of obstetric and gynecological care to the female population of Ukraine at the primary level of its provision were identified in the research. They include, first of all, the training of family physicians and family nurses to provide medical services to the female population and the coordination of primary care and specialized obstetric and gynecological services.

Conclusions: The priority of application of management and organizational measures for the effective integration of obstetric and gynecological care to the female population of Ukraine to the primary level of its provision was determined by an expert way.
\end{abstract}

KEY WORDS: obstetric and gynecological care, primary level, integration, priorities, expert determination

Wiad Lek. 2021;74(3 p.II):647-651

\section{INTRODUCTION}

A comprehensive reform of the health care system [1-3] with the priority development of primary health care on the basis of general medical practice-family medicine $[4,5]$ and the introduction of a fundamentally new system of financing health care facilities for medical care services within the package of free state guarantees [6] is carrying out in Ukraine. At the legislative level, it is determined that the responsibilities of family doctors include the provision of comprehensive obstetric and gynecological care to women [7]. At the same time, in the publications of recent years, it has been established that the primary care unit in Ukraine is not sufficiently prepared to provide women with this type of medical care [8 ]. All above mentioned determined the relevance of this study.

\section{THE AIM}

To determine the priority directions for the integration of obstetric and gynecological care for the female population of Ukraine to the primary level of its provision.

\section{MATERIALS AND METHODS}

Sociological, statistical and bibliosemantic methods were used in the research. The systematic approach was the methodological basis of the study. 79 health care providers, 127 family doctors, 92 obstetrician-gynecologists, and 248 women as providers and consumers of obstetric-gynecological medical services were interviewed as experts by a special questionnaire. The competence of medical workers was determined by their highest and first attestation categories.

The results obtained in the study were processed using generally accepted statistical methods.

The application of these methods in the study was reviewed and approved by the committee on ethics of state higher educational institution «Uzhhorod National University» (protocol No. 3 of December 11, 2020).

\section{RESULTS}

At the beginning of the study, the approaches of primary health care activities of the obstetric and gynecological services were determined by an expert way. The results of the expert way are presented in table1.

The following positions received the highest assessment from the experts: the preventive examinations to detect visual forms of malignant neoplasms in the early stages of development $(100.0 \%$ of health care providers, family doctors, obstetricians-gynecologists assessed this form of activity, women $-96.4 \%$ ), the complex information 
Table I. The forms of activity of primary health and gynecological services care for the provision of obstetric and gynecological services (results of an expert assessment)

\begin{tabular}{|c|c|c|c|c|c|c|c|c|}
\hline \multirow[t]{2}{*}{$\begin{array}{l}\text { The forms of activity and types } \\
\text { of medical services }\end{array}$} & \multicolumn{2}{|c|}{$\begin{array}{l}\text { Health care } \\
\text { providers }\end{array}$} & \multicolumn{2}{|c|}{ Family doctors } & \multicolumn{2}{|c|}{$\begin{array}{l}\text { Doctors } \\
\text { obstetricians- } \\
\text { gynecologists }\end{array}$} & \multicolumn{2}{|c|}{ Women } \\
\hline & abs. & $\%$ & abs. & $\%$ & abs. & $\%$ & abs. & $\%$ \\
\hline $\begin{array}{l}\text { The complex information and educational activity } \\
\text { among the female population on disease prevention } \\
\text { and preservation of the reproductive health }\end{array}$ & 74 & 93.7 & 125 & 98.4 & 92 & 100.0 & 240 & 96.8 \\
\hline $\begin{array}{l}\text { An informational and educational activity among } \\
\text { adolescent girls on safe sexual behavior and } \\
\text { preservation of reproductive health }\end{array}$ & 75 & 94.9 & 120 & 94.5 & 87 & 94.6 & 227 & 91.5 \\
\hline $\begin{array}{l}\text { Educational work among parents of adolescent girls } \\
\text { and teachers, informing them about the features of } \\
\text { educational work during the puberty period }\end{array}$ & 72 & 91.1 & 112 & 88.2 & 83 & 90.2 & 201 & 81.0 \\
\hline $\begin{array}{l}\text { The conducting preventive examinations to detect } \\
\text { visual forms of malignant neoplasms in the early } \\
\text { stages of development }\end{array}$ & 79 & 100.0 & 127 & 100.0 & 92 & 100.0 & 239 & 96.4 \\
\hline Providing family planning counseling services & 70 & 88.6 & 120 & 94.5 & 87 & 94.6 & 217 & 87.5 \\
\hline $\begin{array}{l}\text { The management of pregnant women with the } \\
\text { physiological course of gestation }\end{array}$ & 72 & 91.1 & 117 & 92.1 & 82 & 89.1 & 192 & 77.4 \\
\hline Organization of the School for Responsible Parenting & 74 & 93.7 & 112 & 88.2 & 82 & 89.1 & 187 & 75.4 \\
\hline Medical monitoring of women in the postpartum period & 72 & 91.1 & 117 & 92.1 & 82 & 89.1 & 192 & 77.4 \\
\hline $\begin{array}{l}\text { The diagnosis and medical care for women with the } \\
\text { most common gynecological diseases }\end{array}$ & 70 & 88.6 & 109 & 85.8 & 83 & 90.2 & 194 & 78.2 \\
\hline $\begin{array}{l}\text { The provision of counseling services for the } \\
\text { prevention of sexually transmitted infections, their } \\
\text { syndrome diagnosis and treatment }\end{array}$ & 63 & 79.7 & 105 & 82.7 & 74 & 80.4 & 171 & 68.9 \\
\hline $\begin{array}{l}\text { Providing emergency medical care in obstetrics and } \\
\text { gynecology problems to women }\end{array}$ & 75 & 94.9 & 125 & 98.4 & 88 & 95.7 & 201 & 81.0 \\
\hline $\begin{array}{l}\text { The referral, if necessary, of women to receive } \\
\text { specialized medical care at the highest levels }\end{array}$ & 79 & 100.0 & 127 & 100.0 & 92 & 100.0 & 248 & 100.0 \\
\hline
\end{tabular}

and educational activity among the female population on disease prevention and preservation of the reproductive health $(93.7 \%, 98.4 \%, 100.0 \%$ and $96.8 \%$, respectively), an informational and educational activity among adolescent girls on safe sexual behavior and preservation of reproductive health $(94.9 \%, 94.5 \%, 94.6 \%, 91.5 \%$, respectively), providing emergency medical care in obstetrics and gynecology problems to women $(94.9 \%, 98.4 \%, 95.7 \%$ and 81.0 $\%$ respectively), referral, if necessary, of women to receive specialized medical care at the highest levels (supported by all experts). At the same time, the following positions of obstetric and gynecological care at the primary level received the lowest assessment of experts: the provision of counseling services for the prevention of sexually transmitted infections, their syndrome diagnosis and treatment $(79.7 \%, 82.7 \%, 80.4 \%, 68.9 \%)$, diagnosis and medical care for women with the most common gynecological diseases ( $88.6 \%, 85.8 \%, 90.2 \%, 78.2 \%$, respectively).

The level of support by women for certain obstetric-gynecological services at the primary level was assessed by us as the level of their primary attachment to receive these services from the family doctors. According to the expert survey, the level of commitment of women to receive certain obstetric and gynecological medical services from family doctors is not high.

The next step of the study was an expert assessment of the priority of management measures to ensure the effective integration of obstetric and gynecological care at the primary level. We divided the necessary management measures that need to be taken for the effective integration of obstetric and gynecological care at the primary level according to the levels of their adoption: sectoral, regional, territorial and local. The results of the expert assessment are presented in table 2 .

The following management decisions had the highest assessment of experts: to approve the local motivational mechanisms for family doctors and family nurses at the level of territorial communities $(100.0 \%$ of health care providers and family doctors assessed this form of activity, obstetricians-gynecologists $-89.1 \%$, women $-92.7 \%$ ), to approve the rational routes for women with obstetric and gynecological pathology at the level of administrative territories (100.0\%, $96.8 \%, 92.4 \%, 92.7 \%$ respectively), to improve the table of equipment of family outpatient clinics in accordance with 
Table II. The priority of management measures to ensure the effective integration of obstetric and gynecological care at the primary level (results of an expert assessment)

\begin{tabular}{|c|c|c|c|c|c|c|c|c|}
\hline \multirow[t]{2}{*}{$\begin{array}{l}\text { The forms of activity and types } \\
\text { of medical services }\end{array}$} & \multicolumn{2}{|c|}{$\begin{array}{l}\text { Health care } \\
\text { providers }\end{array}$} & \multicolumn{2}{|c|}{ Family doctors } & \multicolumn{2}{|c|}{$\begin{array}{l}\text { Doctors } \\
\text { obstetricians- } \\
\text { gynecologists }\end{array}$} & \multicolumn{2}{|c|}{ Women } \\
\hline & abs. & $\%$ & abs. & $\%$ & abs. & $\%$ & abs. & $\%$ \\
\hline $\begin{array}{l}\text { At the level of territorial communities - to approve } \\
\text { complex plans for the integration of obstetrical and } \\
\text { gynecological care at the primary level. }\end{array}$ & 73 & 92.4 & 122 & 96.1 & 81 & 88.0 & 216 & 87.1 \\
\hline $\begin{array}{l}\text { At the level of public health centers - to prepare and } \\
\text { spread among family doctors the methodological } \\
\text { materials for conducting comprehensive informational } \\
\text { and educational activity. }\end{array}$ & 78 & 98.7 & 127 & 100.0 & 90 & 97.8 & 245 & 98.8 \\
\hline $\begin{array}{l}\text { At the level of the Ministry of Health Ukraine - to } \\
\text { improve the table of equipment of family outpatient } \\
\text { clinics in accordance with the medical services in } \\
\text { obstetrical and gynecological care }\end{array}$ & 78 & 98.7 & 125 & 98.4 & 91 & 98.9 & 241 & 97.2 \\
\hline $\begin{array}{c}\text { At the level of territorial communities - to approve } \\
\text { local motivational mechanisms for family doctors and } \\
\text { family nurses. }\end{array}$ & 79 & 100.0 & 127 & 100.0 & 82 & 89.1 & 230 & 92.7 \\
\hline $\begin{array}{c}\text { At the level of the Ministry of Health Ukraine - to } \\
\text { approve the division of responsibilities between } \\
\text { family doctors and family nurses for the provision of } \\
\text { medical care to women. }\end{array}$ & 72 & 91.1 & 115 & 90.6 & 84 & 91.3 & 225 & 90.7 \\
\hline $\begin{array}{l}\text { At the level of administrative territories - to approve } \\
\text { the rational routes for women with obstetric and } \\
\text { gynecological pathology. }\end{array}$ & 79 & 100.0 & 123 & 96.8 & 85 & 92.4 & 230 & 92.7 \\
\hline $\begin{array}{l}\text { At the level of primary health care centers to approve } \\
\text { plans-schedules for theoretical and practical training } \\
\text { of family doctors and family nurses to provide the } \\
\text { certain obstetrical and gynecological services. }\end{array}$ & 74 & 93.7 & 125 & 98.4 & 90 & 97.8 & 238 & 95.9 \\
\hline $\begin{array}{l}\text { At the level of higher medical establishments - to } \\
\text { develop the educational programs in the universities } \\
\text { to train family doctors and family nurses to provide } \\
\text { comprehensive obstetric and gynecological services. }\end{array}$ & 74 & 93.7 & 125 & 98.4 & 87 & 94.6 & 238 & 95.9 \\
\hline $\begin{array}{c}\text { At the level of administrative territories - to } \\
\text { approve the mechanisms of interaction between } \\
\text { family doctors and specialized obstetric and } \\
\text { gynecological services. }\end{array}$ & 72 & 91.1 & 117 & 92.1 & 84 & 91.3 & 230 & 92.7 \\
\hline
\end{tabular}

the medical services of obstetrical and gynecological care at the level of the Ministry of Health Ukraine $(98.7 \%, 98.4 \%$, $98.9 \%, 97.2 \%$ respectively), to approve complex plans for the integration of obstetrical and gynecological care at the primary level at the level of territorial communities ( $92.4 \%$, $96.1 \%, 88.0 \%, 87.1 \%$, respectively).

The necessity to develop educational programs in the universities to teach family doctors and family nurses to provide comprehensive obstetric and gynecological services and the approval of plans-schedules for theoretical and practical training of family doctors and family nurses at the level of primary health care centers to provide the certain obstetrical and gynecological services received the high level of the assessment by the experts.

The experts determined the prioritization of organizational measures to ensure the effective integration of obstetric and gynecological care at the primary level. The results of which are demonstrated in table 3. It was found that all experts supported .

The necessity to provide family doctors with the methodological and visual materials for carrying out informative and educational activity among the female population and almost all experts supported the necessity to train family doctors and family nurses to conduct preventive examinations of women.

The priority of organizational activities as a teaching of the family doctors and family nurses to diagnose pregnancy, management of pregnant women and women in the postpartum period $(94.9 \%$ of the health care providers assessed this form of activity, family doctors and obstetricians-gynecologists $-100.0 \%$ each, women $-81.0 \%$ ), as well as a training of the family doctors and family nurses to provide emergency medical care in obstetrics and gynecology to women $(96.2 \%, 98.4 \%, 100.0 \%, 89.9 \%$, respectively) 
Table III. The priority of organizational measures to ensure the effective integration of obstetric and gynecological care at the primary level (results of an expert assessment, $\% \pm m$ )

\begin{tabular}{|c|c|c|c|c|c|c|c|c|}
\hline \multirow[t]{2}{*}{$\begin{array}{l}\text { The forms of activity and types } \\
\text { of medical services }\end{array}$} & \multicolumn{2}{|c|}{$\begin{array}{l}\text { Health care } \\
\text { providers }\end{array}$} & \multicolumn{2}{|c|}{ Family doctors } & \multicolumn{2}{|c|}{$\begin{array}{l}\text { Doctors } \\
\text { obstetricians- } \\
\text { gynecologists }\end{array}$} & \multicolumn{2}{|c|}{ Women } \\
\hline & abs. & $\%$ & abs. & $\%$ & abs. & $\%$ & abs. & $\%$ \\
\hline $\begin{array}{l}\text { A providing of family doctors with the } \\
\text { methodological and visual materials for conducting } \\
\text { informational and educational activity among the } \\
\text { female population. }\end{array}$ & 79 & 100.0 & 127 & 100.0 & 92 & 100.0 & 248 & 100.0 \\
\hline $\begin{array}{c}\text { A providing of family doctors with the } \\
\text { methodological and visual materials for educational } \\
\text { activity among adolescent girls and their parents } \\
\text { and teachers. }\end{array}$ & 72 & 91.1 & 127 & 100.0 & 87 & 94.6 & 217 & 87.5 \\
\hline $\begin{array}{l}\text { To develop a website for each family doctor with a } \\
\text { specialized informative section for women. }\end{array}$ & 75 & 94.9 & 120 & 94.5 & 85 & 92.4 & 207 & 83.5 \\
\hline $\begin{array}{l}\text { A providing of the family outpatient clinics with } \\
\text { medical supplies necessary for the provision of } \\
\text { obstetric and gynecological services. }\end{array}$ & 72 & 91.1 & 122 & 96.1 & 84 & 91.3 & 241 & 97.2 \\
\hline $\begin{array}{l}\text { A formation of women's commitment to receive } \\
\text { medical care from family doctors. }\end{array}$ & 73 & 92.4 & 115 & 90.6 & 83 & 90.2 & 209 & 84.3 \\
\hline $\begin{array}{l}\text { A preparing of the family doctors and family nurses } \\
\text { for preventive examinations of women }\end{array}$ & 79 & 100.0 & 127 & 100.0 & 92 & 100.0 & 231 & 93.1 \\
\hline $\begin{array}{l}\text { A preparing of the family physicians and family nurses } \\
\text { to provide family planning counseling services. }\end{array}$ & 74 & 93.7 & 120 & 94.5 & 83 & 90.2 & 217 & 87.5 \\
\hline $\begin{array}{l}\text { A preparing of the family doctors and family nurses } \\
\text { to diagnose pregnancy, management of pregnant } \\
\text { women and women in the postpartum period. }\end{array}$ & 75 & 94.9 & 127 & 100.0 & 92 & 100.0 & 201 & 81.0 \\
\hline $\begin{array}{c}\text { A preparing of the family doctors and family nurses } \\
\text { to provide medical care to women with the most } \\
\text { common gynecological diseases. }\end{array}$ & 71 & 89.9 & 117 & 92.1 & 87 & 94.6 & 206 & 83.1 \\
\hline $\begin{array}{c}\text { A preparing of the family doctors and family } \\
\text { nurses to provide services for women with sexually } \\
\text { transmitted infections, their diagnosis and treatment. }\end{array}$ & 65 & 82,2 & 113 & 88,9 & 74 & 88,4 & 192 & 77,4 \\
\hline $\begin{array}{l}\text { A training of the family doctors and family nurses to } \\
\text { provide emergency medical care in obstetrics and } \\
\text { gynecology to women. }\end{array}$ & 76 & 96,2 & 125 & 98,4 & 92 & 100,0 & 223 & 89,9 \\
\hline $\begin{array}{l}\text { The introduction of the mechanisms of interaction } \\
\text { between the family doctors and specialized obstetric } \\
\text { and gynecological services, including rational } \\
\text { routes for women in the cases of the necessity of } \\
\text { specialized medical care }\end{array}$ & 77 & 97,5 & 127 & 100,0 & 90 & 97,8 & 244 & 98,4 \\
\hline
\end{tabular}

and the introduction of the mechanisms of interaction between the family doctors and specialized obstetric and gynecological services, including rational routes for women in the cases of the necessity of specialized medical care (97.5\%, 100.0\%, $97.8 \%, 98.4 \%$, respectively) received a high level of support from experts.

\section{DISCUSSION}

It was determined in our research a sufficiently high level of the support by providers of medical services of the activities of primary health care for the provision of obstetric and gynecological services, which indicates their readiness to integrate the provision of obstetric and gynecological services to the level of primary health care. Thus, the level of support for the provision of certain services by healthcare providers ranges from 79.7-100.0 \%, by family doctors within $82.7-100.0 \%$, by obstetricians-gynecologists $-80.4-100 \%$. The level of support by women, as recipients of medical services, of individual services is lower, between 75.4-100.0\%, which indicates an insufficient level of women's readiness to receive obstetric and gynecological medical care in family doctors.

In order to ensure the effective integration of obstetrical and gynecological services for their provision by family doctors, the experts have supported at different levels of 
ranges the management and organizational measures, which indicates their possible impact on the integration process. At the same time, it is important that all experts support the priority of theoretical and practical training of the family doctors and family nurses for the comprehensive provision of medical services in obstetrics and gynecology and mechanisms for professional interaction between family doctors and specialized obstetric and gynecological services, including the development of the rational routes for women who need specialized obstetrical and gynecological care.

\section{CONCLUSIONS}

It was determined by an expert way the priority of application of management and organizational measures, which must be provided at the all levels of government from the level of united communities to the Ministry of Health of Ukraine, for the effective integration of obstetric and gynecological care to the female population of Ukraine to the primary level of its provision. At the same time, it is ought to pay attention of health care providers to the necessity for the activity on the formation of women's commitment to receive obstetric and gynecological medical services from family doctors.

\section{REFERENCES}

1. Anishchenko 0.V., Moiseienko R.0., Tolstanov 0.K. Pozytyvnyi dosvid reformuvannia haluzi okhorony zdorovia rehioniv [Positive experience of reforming the health care of the regions]. Kyiv. 2011. (in Ukrainian).

2. Popchenko T.P. Reformuvannia sfery okhorony zdorovia Ukrainy: orhanizatsiine, normatyvno-pravove ta nansovo-ekonomichne zabezpechennia (analitychna dopovid) [Healthcare Reform in Ukraine: Organizational, Regulatory, Legal and Financial Support (Analytical Report)]. Kyiv.2011. (in Ukrainian).

3. Potseluiev V.I. Obhruntuvannia systemy monitorynhu yakosti ta dostupnosti medychnoi dopomohy v zakladakh simenoi medytsyny (na prykladi silskoho naselennia Sumskoi oblasti) [Substantiation of the system of monitoring the quality and availability of medical care in family medicine institutions (on the example of the rural population of Sumy region)]. Extended abstract of Candidate's thesis. Kyiv, P. Shupyk National Medical Academy of Postgraduate Education. 2014. (in Ukrainian).

4. OrdynskyiV.A.Medyko-sotsialneobhruntuvannia modelipervynnoimedykosanitarnoi dopomohy silskomu naselenniu na rivni administratyvnoho raionu [Medical and social substantiation of the model of primary health care for rural population at the level of the administrative district]. Extended abstract of Candidate's thesis. Kyiv, P. L. Shupyk National Medical Academy of Postgraduate Education. 2015. (in Ukrainian).

5. Musii O.S. et al. Shchorichna dopovid pro stan zdorovia naselennia, sanitarno-epidemichnu sytuatsiiu ta rezultaty diialnosti systemy okhorony zdorovia Ukrainy. 2013 rik [Annual report on the state of health of the population, the sanitary-epidemic situation and the results of activity of the health care system of Ukraine. 2013]. Kyiv. 2014. (in Ukrainian).
6. Zakon Ukrainy "Pro derzhavni nansovi harantii medychnoho obsluhovuvannia naselennia" № 2168-VIII [Law of Ukraine "On State Financial Guarantees of Public Health Services" October 19, 2017 № 2168-VIII]. http://search.ligazakon.ua/__doc2.nsf/link1/T172168.html. (in Ukrainian).

7. Nakaz MOZ Ukrainy vid 19.03.2018 №504 «Pro zatverdzhennia Poriadku nadannia pervynnoi medychnoi dopomohy». https://moz. gov.ua/article/ministry-mandates/nakaz-moz-ukraini-vid-19032018-504-pro-zatverdzhennja-porjadku-nadannja-pervinnoi-medichnoidopomogi. (In Ukrainian).

8. Shcherbynska 0.S., Slabkyi H.0. Nadannia likariamy zahalnoi praktyky simeinymy likariamy akusherskohinekolohichnoi dopomohy ta kharakterystyka vzaiemoziazku pervynnoi lanky z akusherskohinekolohichnymy sluzhbamy [Provision of general practitioners by obstetric and gynecological family physicians and characterization of primarylink with obstetric/gynecological services]. Simeina medytsynaFamily Medicine. 2019; 3: 63-67. (in Ukrainian).

This article was carried out as a part of the research work "The scientific rationale for monitoring the factors affecting the health of the population of Transcarpathian region and formation of modern management in the health care system" (2016-2021, № state registration 0115U003907).

The work was performed within the framework of the Scientific Research Work "Scientific Support for Regional Health Care Reform" / Code 51A-2015, State Registration Number $0112 U 001923$.

\section{ORCID and contributionship:}

Olena S. Shcherbinska: 0000-0002-5401-7110 A, B, C, D, E, F Hennady O. Slabkiy: 0000-0003-2308-7869 ${ }^{B, C, D}$

\section{Conflicts of Interest:}

The Authors declare no conflict of interest.

\section{CORRESPONDING AUTHOR Hennady 0. Slabkiy \\ Uzhorod National University \\ 3 Narodna sq., 88001 Uzhhorod, Ukraine \\ tel: +380501711648 \\ e-mail: gennadiy.slabkiy@uzhnu.edu.ua}

Received: 15.10 .2020

Accepted: 05.03.2021

A - Work concept and design, B - Data collection and analysis, C - Responsibility for statistical analysis, D-Writing the article, $\mathbf{E}$-Critical review, $\mathbf{F}$ - Final approval of the article 